\title{
Pleural Mesothelioma cM0 TNM Finding v7
}

National Cancer Institute

\section{Source}

National Cancer Institute. Pleural Mesothelioma cMO TNM Finding v7. NCI Thesaurus. Code C88916.

Pleural mesothelioma without evidence of distant metastasis. (from AJCC 7th Ed.) 